\title{
Manuscript World, Print World, Digital World
}

$\mathbf{1}$

Three Worlds

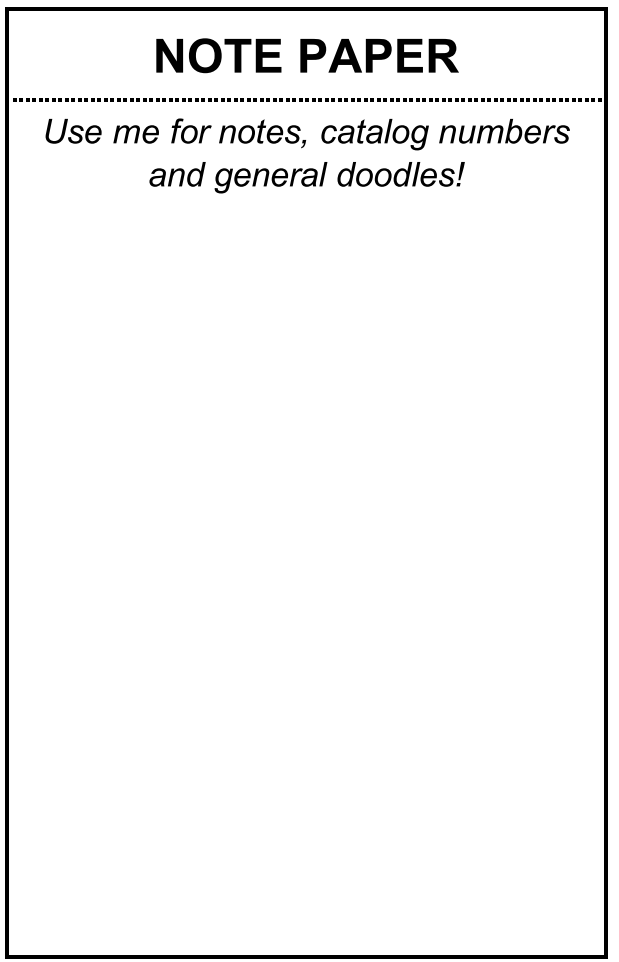

This is how the slip of paper I found at the Cambridge University Library looked like. ${ }^{1}$ Its font and layout clearly tell us that it was originally made on a computer: it is a born-digital document. By means of mechanical application of ink onto paper, it was transformed into a print publication. Its use, however, is primarily for people to scribble (Latin: scribere) on by hand (Latin: manus): it is a manuscript in the making. It exists as all three simultaneously, though few would recognize it as such. Its digital aspect would elude even the most veteran library patrons. Its creator, quite likely, did not think of it as a print publication. And apparently, Cambridge University's current students have a

1 Note the mischievous absence of the Oxford comma.

(C) CORNELIS VAN LIT, 2020 | DOI:10.1163/9789004400351_003

This is an open access chapter distributed under the terms of the CC-BY-NC-ND 4.0 License.

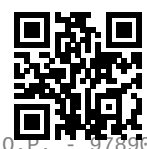


hard time figuring out that it is a potential manuscript, given that its function needs to be called attention to.

Such cross-over artifacts populate our world. And digitized manuscripts, the topic of this book, is a prime example of this. In this chapter, I analyze the double or triple natures of such artifacts to understand their implications.

I wish to frame my analysis by arguing that material manuscripts, printed publications, and digital documents each form what I call a world, each with its own communication system, its own episteme or consciousness, its own power structure, and its own social dynamic. The reason I chose 'world' and not, for example, 'era' is illustrated already in this example. Manuscripts, printed publications, and digital documents do not live independently of each other, as though they would convey the same message but in a different medium, at a different point in history. Words like 'condition' or 'culture' also do not cover the entire phenomenon, ${ }^{2}$ as they can only be understood when contrasted with a notion like 'technology,' as we shall see. It is true that the technology for manuscripts, printed publications, and digital documents, and the cultures they produced, arose in different parts of history and can be arranged in a rough chronology. ${ }^{3}$ Nonetheless, they also do exist simultaneously, sometimes even combined in one artifact, as is the case with the library slip.

The oral/written dichotomy, it may be noted, plays no role in this analysis. Our ways of looking at the world rely too much on writing to consider the dichotomy having great explanatory value. ${ }^{4}$ One aspect that sheds light on the differences between manuscript, print, and digital world, and is therefore worth mentioning here, is the representation of the authority of orality. In most serious cases, such as the court of law or political committees, people are summoned to appear in person and tell what they know, not just write..$^{5}$ It is

2 Illustrated nicely by Jerome McGann who uses both and also 'era' and 'age'. McGann, J. A New Republic of Letters: Memory and Scholarship in the Age of Digital Reproduction. Cambridge Mass.: Harvard University Press, 2014. Harold Love gives a succinct overview of different takes on this, from which I follow the first take, which looks at 'print culture' as a 'noetic world.' Love, H. "Early Modern Print Culture: Assessing the Models." pp. 45-64 in Parergon 20, no. 1 (2003).

3 Too many studies take chronology as their analytical framework, e.g. Bolter, J.D. Writing Space: Computers, Hypertext, and the Remediation of Print. Mahwah: Lawrence Erlbaum, 2001; Eliot, S., and J. Rose. A Companion to the History of the Book. Oxford: Blackwell Publishing, 2007; cf. Finkelstein, D., and A. McCleery. An Introduction to Book History. London: Routledge, 2005, p. 17; cf. Dagenais, J. The Ethics of Reading in Manuscript Culture: Glossing the Libro de Buen Amor. Princeton: Princeton University Press, 1994, p. 16; McGann, pp. 10, 23; Love, p. 46.

4 Ong, W.J. Orality and Literacy. London: Routledge, 2002 [Or. 1982], pp. $77 \mathrm{ff}$.

5 Cf. Ong, p. 94; Love, p. 51; Pedersen, J. The Arabic Book. Translated by G. French. Princeton: Princeton University Press, 1984, p. 17. 
striking how the manuscript world takes over this authoritativeness: a contract still needs to be hand signed in most cases, even if it is only going to be scanned and stored digitally. Similarly, an autographed copy of a printed book can be worth a lot more than a regular copy. In other words, some of the print's value is derived from bringing it into the manuscript world.

My starting point, rather, is that matter matters; ${ }^{6}$ the same text, say, the Koran or Homer's Iliad, is fundamentally different when conveyed through a manuscript, a print edition, or a digital version. Analyses of all three distinct worlds are very rare. ${ }^{7}$ Scholars often conflate them, either grouping manuscripts and printed publications together against digital documents, or considering printed publications and digital documents as the same against manuscripts. All three can even be conflated to the same thing, arguing that abstract ideas are neutrally conveyed through a medium of one's choice, as an idea can stand on its own, without an expression, while an expression is meaningless without a referent. This perhaps rests on principles in Ancient philosophy, such as the ontologically real precedence of form over matter, active over passive, and intellectual over sensory perception-principles that have loomed large until the Enlightenment, and even then it found some home within Idealism. That, however, would be a discussion about ontology and epistemology in a vacuum. ${ }^{8}$ Any person comes about in a social context. Consciousness itself, in the sense of one's 'inner dialogue,' can arguably only arise through the signs one's culture-especially language - provides..$^{9}$ But language, in turn, is decided upon previously and, therefore, is hardly a neutral medium. It is, rather,

6 Cf. Kittler, F.A. Gramophone, Film, Typewriter. Translated by G. Winthrop-Young and M. Wutz. Stanford: Stanford University Press, 1999 [Or. 1986], p. xxxix; Hayles, N.K. Writing Machines. Cambridge Mass.: The Mit Press, 2002, p. 6.

7 Notable exceptions are Johnston and Van Dussen who speak of "manuscript culture," "print culture," and "digital culture." Johnston, M., and M. Van Dussen. "Introduction: Manuscripts and Cultural History." pp. 1-16 in The Medieval Manuscript Book: Cultural Approaches. Cambridge: Cambridge University Press, 2015.

8 Like Descartes attempted with his cogito-argument, or Ibn Tufayl attempted with his allegory of the man growing up alone on an island.

9 Personally, I think that the mode of expression, the garb under which real knowledge expresses itself in the mind, is indeed subject to contextualization. I would call this a localized truth. However, this does not preclude a belief in transcendental, non-discursive thoughts that can nonetheless be called knowledge, real knowledge, objective and invulnerable to localization. As McLuhan writes, "The content of writing is speech [...] If it is asked 'What is the content of speech?', it is necessary to say, 'It is an actual process of thought, which is in itself nonverbal." McLuhan, M. Understanding Media: The Extensions of Man. Cambridge Mass.: MIT Press, 1994 [Or. 1964], p. 8. Cf. Wittgenstein's famous statement "The limits of my language mean the limits of my world." Wittgenstein, L. Tractatus Logico-Philosophicus. Translated by D.F. Pears and B.F. McGuinness. London: Routledge, 2001 [1921], p. 68. 
an "ideological phenomenon par excellence," as Valentin Volosinov puts it, concluding that "the individual consciousness is a social-ideological fact," ${ }^{10}$ which is best revealed "in the material of the word."11 Indeed, not only is it best revealed, but it is also only able to come about by its materiality. Signs that fall out of use lose their force, "becoming the object not of live social intelligibility but of philological comprehension." ${ }^{12}$ Material signs, in that sense, have a worldview-making potential that needs to be re-activated constantly in others to keep a sense of community fresh in our imagination, ${ }^{13}$ and indeed to preserve its own power to which people have submitted themselves. ${ }^{14}$ Otherwise, a process of disenchantment (Entzauberung), hard to reverse, occurs. Seen this way, Nelson Goodman can turn that Idealist paradigm upside down. Instead of ideas being able to do without expressions, he says: ${ }^{15}$

Although conception without perception is merely empty, perception without conception is blind (totally inoperative). Predicates, pictures, other labels, schemata, survive want of application, but content vanishes without form. We can have words without a world but no world without words or other symbols.

The word 'form' here has flipped its meaning. Whereas in Ancient philosophy it is used to denote the essence that is abstract from matter, for Goodman it indicates the specificity of exactly that matter, which is best specified through words. And, as Ong has demonstrated, those words are written words. In "the new world of writing," he says, we are "beings whose thought processes do not grow out of simply natural powers but out of these powers as structured, directly or indirectly, by the technology of writing." ${ }^{16}$ Such an ontology, based not on substance but function, ${ }^{17}$ constructs the world as a social world, this

10 Volosinov, V.N. Marxism and the Philosophy of Language. Translated by L. Matejka and I.R. Titunik. New York: Seminar Press, 1973, p. 12.

11 Volosinov, p. 14.

12 Volosinov, p. 23.

13 Anderson, B. Imagined Communities. 2nd ed. London: Verso, 2006.

14 Althusser, L. "Ideology and Ideological State Apparatuses." pp. 127-88 in Lenin and Philosophy and Other Essays, translated by B. Brewster. New York: Monthly Review Press, 1971, p. 132. Cf. also Levi-Strauss's remark on writing as facilitator of (societal) slavery: Lévi-Strauss, C. Tristes Tropiques. Translated by J. Russell. New York: Criterion Books, 1961, pp. 291-293.

15 Goodman, N. Ways of Worldmaking. Indianapolis: Hackett Publishing, 1978, p. 6.

16 Ong, p. 77 .

17 Goodman, p. 7 . 
construction occurring through the continuous re-activation of signs. ${ }^{18}$ Such continuous re-activation by one person can be called a habit, and a recurring habit across society can be called an institution. ${ }^{19}$ Such institutions are built from people's behavior, but if they grow big enough, the power dynamic reverses and institutions stipulate people's behavior, thereby giving boundaries to their ethics. This is especially true for later generations of people who consider institutions as a matter of fact rather than a social construct. As Peter Berger says, "the reflective integration of discrete institutional processes reaches its ultimate fulfillment. A whole world is created," ${ }^{20}$ and so we see the confirmation for our choice of the term 'world' again. Furthermore, this world "is experienced as an objective reality."21 If Berger is right, it means that the moment this worldview is created, in a dialectical, hermeneutic circle between the individuals and the institutions, the next area of philosophy to be influenced is epistemology. The signs that are given to an individual to express themselves provide the framework in which new items of knowledge are to be expressed. In this sense, it provides boundaries to the knowable, ${ }^{22}$ defining what a good question is and what a good answer might look like. This, it seems to me, is relatable to Michel Foucault's notion of episteme, which "defines the conditions of possibility of all knowledge."23 To get grips of such an episteme, he asks us to look at "surfaces of their emergence," "the authorities of delimitation," and "the grids of specification." ${ }^{24}$ These can be related respectively to the individuals, the power of institutions over habits, and the influence of habits on institutions. I bring up Foucault's version of this phenomenon not only to provide a way in for those familiar with his work, but also because his three-point description is useful for our context. In this book, we set up this theoretical framework in order to understand how material manuscripts, printed publications, and digital documents each form a world, how these worlds are different from each other, and what happens when these world intermesh (or collide).

On a most general and literal level, the 'surfaces of emergence' are, of course, the vellum of the manuscript, the page of the printed publication, and

18 Cf. Dagenais, p. 14.

19 Berger, P.L., and T. Luckmann. The Social Construction of Reality: A Treatise in the Sociology of Knowledge. London: Penguin Books, 1966 [Reprint 1991], pp. 7off.

20 Berger, p. 114.

21 Berger, p. 77.

22 Berger, p. 83.

23 Foucault, M. The Order of Things: An Archeology of the Human Sciences. New York: Vintage Books, 1994 [Or. 1966], p. 168.

24 Foucault, M. The Archeology of Knowledge. Translated by A.M.S. Smith. New York: Pantheon Books, 1972, pp. 41-42. 
the electronic interface of the digital document. These 'surfaces,' I suggest, can be further split between society-based surfaces and object-based surfaces. For society, we shall consider the notions of archive, time, and the dichotomy of center/periphery. For objects, we shall consider the notions of ecosystem, page, and transparency.

As institutions, 'authorities of delimitation,' we can distinguish three levels. One metaphysical, worldview level, one at the level of society, and one at the level of individual actors. The first one consists of the notions of reality and truth. The second consists of canon. I have formed the last using the notions of gatekeepers and producers.

For the 'grids of specification,' the habits, I wish to structure the analysis by three subcategories: possession, engagement, and product. For possession, we shall use the notions of monetized product, ownership, and value. For engagement, we have closely related terms of activity, conversation, reading, and response. For product, we use the illusion of fixity, and product.

All of these notions make the manuscript, print, and digital worlds remarkably different from each other. My analysis proposes the trichotomies as sketched out in the tables below. The differences were condensed into as few words as possible, preferably one, to make the summary overview as compact as possible while maximally highlighting the differences. For some of the trichotomies, you might easily understand what I am pointing out; nonetheless, the next half of the chapter is devoted to a more in-depth description of each notion. If you rather prefer to see these differences put into practice, you can go over to the second half of this chapter, which consists of three case studies that use these notions to highlight the difference between manuscript and print world, print and digital world, and manuscript, print, and digital world, respectively.

TABLE $1.1 \quad$ Surfaces of emergence

\begin{tabular}{llll}
\hline & Manuscript world & Print world & Digital world \\
\hline Page & arbitrary & neutral and fixed & non-existent \\
Transparency & little & some & greatest \\
Ecosystem & faint notion & agnostic & acknowledged \\
Center & local & regional & global \\
Archive & just-as-requested & just-in-case & just-in-time \\
Time & enduring & progressive & of the moment \\
\hline
\end{tabular}


TABLE 1.2 Authorities of delimitation

\begin{tabular}{llll}
\hline & Manuscript world & Print world & Digital world \\
\hline Producers & reader & medium & author \\
Gatekeepers & society & publishers & tech industry \\
Canon & continuous & staggered & $\begin{array}{l}\text { haphazard } \\
\text { reality-replacing } \\
\text { Reality }\end{array}$ \\
Truth & reality-making & reality-stating & post-truth \\
\hline
\end{tabular}

TABLE 1.3 Grids of specification

\section{Manuscript world Print world Digital world}

\begin{tabular}{|c|c|c|c|}
\hline Monetization & codex & text & user \\
\hline Value & a lot & some & a little \\
\hline Ownership & $\begin{array}{l}\text { privately owned, } \\
\text { privately made }\end{array}$ & $\begin{array}{l}\text { privately owned, } \\
\text { corporately made }\end{array}$ & $\begin{array}{l}\text { corporately owned, } \\
\text { corporately made }\end{array}$ \\
\hline Activity & active & reactive & interactive \\
\hline Reading & charitable & docile & egotistical \\
\hline Response & in the margin & another text & within the text \\
\hline Conversation & dialogue & monologue & soliloquy \\
\hline Product & process in flux & end result & end result in flux \\
\hline Fixity & non-existent & strong & illusion \\
\hline
\end{tabular}

\subsection{Surfaces of Emergence \\ 1.1.1 Object-based}

The sequence of words that forms a text can manifest itself in any of the worlds, manuscript, print, and digital. In the manuscript world, its fundamental surface of emergence is the folio. This can be of any material, but it is most likely papyrus, parchment, or paper. Its size and color are largely inconsequential; variations in them are taken as a matter of fact and whatever is needed to complete copying the text is used. Further, the entire folio is of importance, in contrast to print publications, where, in principle, only the text block is important. For manuscripts, however, as John Dagenais famously noted, "it is at the edges of manuscripts [...] that the most important part of 'medieval literature' happens." ${ }^{25}$ For printed publications, the page is the surface of emergence.

Dagenais, p. xvi. 
This is a carefully chosen delimiter of the text. ${ }^{26}$ Each page is meant to be cut alike and is often white as snow. It bears with it a great consequence, namely the page number, which functions in the print world as the ultimate neutral decider of the place of a text. For example, at the final stage of print proofs, authors are asked not to request changes that would push text onto the next page. Page numbers have assumed such great power that their functionality has been projected onto the manuscript and the digital world when referring to a source from either world. For the digital world, the fundamental surface of emergence is the interface, by which I mean more than just the pixels in a monitor. The interface is the entirety of the user experience, from storage in bits and bytes, through a file type and operating system, to a monitor and peripherals to give instructions to the computer. The durability of these surfaces is notably different; manuscripts, especially those of parchment or paper, can be incredibly durable and sturdy, easily surviving many centuries. Print publications have often greatly reduced the quality of their materials. With wood pulp mixed in paper and using glue for binding instead of sewing the quires, modern books can quite literally fall apart into unusable pieces. Digital documents, in turn, have seen a very fast outdating. Whereas hardware upgrading usually only means improvement, software upgrading can render file types obsolete and unusable. Within mere decades, a digital document can become practically inaccessible.

Despite the volatility of digital documents, the transparency of its surface of emergence is the greatest of all. ${ }^{27}$ This is encouraged by tech companies which hide as much as possible from the user. Jason Merkoski, former lead-engineer of Amazon's electronic reading device says: "The Kindle itself is just the tip of the iceberg, and its true workings are invisible. That's exactly how Amazon wanted it to be." ${ }^{28}$ The fact that somebody accesses the text through a specific hardware and software setup remains virtually always unacknowledged. Rather, as Lori Emerson has analyzed well, the interface of digital documents is purposely made as transparent as possible using a blinding seduction of offering supposed natural usability without the need of a manual. ${ }^{29}$ She concludes

26 Mak, B. How the Page Matters. Toronto: University of Toronto Press, 2011, esp. p. 3, 73.

27 Kichuk, D. "Metamorphosis: Remediation in Early English Books Online (EE BO)." pp. 291303 in Literary and Linguistic Computing 22, no. 3 (2007), pp. 296-297; Foys, M.K. "Medieval Manuscripts: Media Archaeology and the Digital Incunable." pp. 119-39 in The Medieval Manuscript Book: Cultural Approaches, edited by M. Van Dussen and M. Johnston, Cambridge: Cambridge University Press, 2015, p. 119.

28 Merkoski, J. Burning the Page: The Ebook Revolution and the Future of Reading. Naperville: Sourcebooks, 2013, p. xvi.

29 Emerson, L. Reading Writing Interfaces: From the Digital to the Bookbound. Minneapolis: University of Minnesota Press, 2014, esp. pp. x, 2-5, 24. 
that this veil of ignorance can, does, and will change the nature of the digital world from one of true creativity towards merely being offered predetermined choices that are carefully restricted by corporations. She concludes that "now, digital interfaces are artful only to the extent that they don't work,"30 as only when digital interfaces do not work is the veil removed and we are reminded that there must be inner workings to the technology we use.

In the limited cases that digital documents are considered in their materiality, users pretend they are (like) print publications. ${ }^{31} \mathrm{~A}$ computer still provides, as it were, a transparent window onto the document. ${ }^{32}$ McLuhan already wrote in the sixties that "the electric light escapes attention as a communication medium just because it has no 'content."'33 This transparency is augmented by the shared control of writer and reader over the text's appearance (in fact, both think they have sole control, not considering the other). ${ }^{34}$ These are fundamental misunderstandings, though easy to make within the paradigm of the digital world. In this paradigm, the vocabulary is concentrated upon user experience, with the computer merely seen as a tool that can be used in whatever way the user wants to. The medium itself is transparent, invisible, and its influence on the message is not considered. It is this mistaken transparency that is the subject of the next chapter, where we discuss the phenomenon of digitized manuscripts. For print, transparency means the page and the uniformity of the print faces. ${ }^{35}$ In its supposed neutrality, it fades into the background for the reader. This is how Stephen Nichols remarks that "the medieval artifact, for Spitzer, was the edited text," ${ }^{\prime 36}$ not the manuscript evidence which underlies the critical edition. Not so for manuscripts, where readers are much more aware of the specificity of the folio, its ornamentation, even the style

3o Emerson, p. 4, cf. her discussion of easter eggs and glitches, pp. 24, 36.

31 Mandell, L. Breaking the Book: Print Humanities in the Digital Age. Chichester: WileyBlackwell, 2015, p. 3; Sutherland, K. "Being Critical: Paper-Based Editing and the Digital Environment." pp. 13-26 in Text Editing, Print and the Digital World, edited by M. Deegan and K. Sutherland. Surrey: Ashgate, 2009, p. 19; Eggert, P. "The Book, the E-Text and the 'Work-Site." pp. 63-82 in Text Editing, Print and the Digital World, edited by M. Deegan and K. Sutherland, Surrey: Ashgate, 2009, p. 67; Weiss, A. Using Massive Digital Libraries. Chicago: ALA TechSource, 2014, pp. 7-8.

32 Cf. Sutherland, "Being Critical," pp. 17-18.

33 McLuhan, p. 9.

34 Lanham, R.A. "The Electronic Word: Literary Study and the Digital Revolution." pp. 265290 in New Literary History 20, no. 2 (1989), p. 266.

35 Lanham, p. 266; Mak, p. 8.

36 Nichols, S.G. "Introduction: Philology in a Manuscript Culture." pp. 1-10 in Speculum 65, no. 1 (1990), p. 3 . 
of handwriting. Perhaps only the letters themselves provide some sense of transparency_as a neutral, effortless means to evoke a certain letter, sound, or word in the reader's mind.

We can also look at the relationship of one object to another: their ecosystem. For manuscripts, each codex is individuated with only a faint notion of it being a copy or exemplar of another manuscript containing the same text. Meanwhile, for print publications, each copy is only a copy. Readers, then, as far away as they may be from each other, share the space that the page dictates since each copy has the same space on a specific page. However, readers are largely agnostic to this as they cannot directly see that they share the space, for example, by interaction. This would be possible for digital documents, which can truly allow for sharing space by enabling multiple users to use one file. Prime examples include the comments section under a news item or a Wikipedia entry.

1.1.2 Society-based

Societal surfaces of emergence are informative as well. Take for instance the center/periphery dichotomy. For manuscripts, local centers are possible as the periphery can produce unimpeded by the power of the center. In the print world, the periphery, one might think, has the leverage to burst out to the rest of the area as one could at once produce and disseminate as many copies as one would like. This, however, is but an illusion: the means of production are too costly to be operated by anybody. The center takes a firmer grip on the periphery. In the digital world, the discourse takes place in its hardware-location, which means that there can be a global center.

Of a different nature is the notion of the archive. For the manuscript world, one codex already is an archive. It can contain different texts, and the margins can be filled with readers' comments. In the world of print, we have a veritable archive fever. This is because the printed paper itself is authoritative, and so it is almost as though whoever has the most paper is most powerful and most correct. There is, therefore, a great incentive to collect print publications and combine them into shelves and shelves of archives. For digital materials, it is not so much the collecting that is of importance. It is important not to be reliant on others, but the collection itself can happen quick and cheap. It is rather the structure and searchability of the archive that is important. If manuscripts are acquired 'just-as-requested' as a self-containing unit which has space within itself for growth, either by sewing in additional quires or writing in the margins, then print publications are acquired 'just-in-case', as their authority will be of weight whether it is ever touched or will forever sit in the archive. 
And in that case, digital documents can be said to be obtained 'just-in-time,' with much fewer demands on the shape and form as long as it can be found in a reasonable time (which, for the digital world, can sometimes be less than a minute).

This brings us to the aspect of time on the surfaces of emergence. Manuscripts, by connecting people who are centuries apart, transcend time. A manuscript can lie dormant only to be picked up three-hundred years later, at which a reader can write notes in the margin, talking back to the author as though they were a contemporary. Print publications, however, have a progressing aspect to them. Whatever is published is the new authority, superseding previous publications. Since the publication is made available to the entire nation or linguistic zone, there is a sense of everybody being lifted onto the next plane of knowledge. The progression is also visible in intertextuality, where the most often cited texts are those that have recently been published, neither immediately nor far in the past. The digital world, in turn, operates in 'real-time.' Especially those documents connected to the internet work best when they reference events that have just happened, or are happening right now. Since documents can be updated without any trace of such operation, a sense of progression is lost.

1.2

Authorities of Delimitation

1.2.1

\section{Actors}

Let us start with the most basic and directly active authorities, what I have called actors. In terms of the producer of a text, the difference between the three worlds could not be greater. For manuscripts, the reader is the producer. ${ }^{37}$ For print publications, the medium - that is, the system of different businesses involved in manufacturing and selling books-is the producer. ${ }^{38}$ For digital documents, it is the author who is the producer.

This is further explained by looking at the different purposes of production. If the above is true then the purpose of manuscripts is to be read, the purpose of print publications is to be transmitted, and the purpose of a digital document is to be written. When a reader in a print world wants to read something, they simply go to a store and buy a copy. However, this only has a bearing on the production of that copy in a second degree; the copy was already made.

37 Cf. Johnston and Van Dussen, p. 5; Dagenais, pp. xvii, pp. 23-24; Blair, A. "Afterword: Rethinking Western Printing with Chinese Comparisons." pp. 349-361 in Knowledge and Text Production in an Age of Print: China, 900-140o, edited by L. Chia and H. De Weerdt, Leiden: Brill, 2011, p. 353 .

38 I strongly disagree with Walter Ong's assertion that "manuscript culture is produceroriented" and "print is consumer-oriented." Cf. Ong, p. 120. 
Compare this with the manuscript world, in which copies of texts are seldomly for sale. Thus, as a rule, if somebody wants to read a text, they need to acquire a copy by literally copying it out from another copy, in other words, the production of that copy is specifically for that reader. ${ }^{39}$ Whether readers do that themselves or ask professional scribes to do it is not important, as the primary agency of the reader is the same in both cases; the reader sets the process of production in motion out of a desire to read. ${ }^{40}$ As Johannes Pedersen describes, even the first time a text is written by its author, it is done in a setting requiring readers, listeners, and a process of back-and-forth proposing and approving. ${ }^{41}$ Not so in the print world. In a span of a few years, in the 1510 , it is said that over 300,000 copies of Luther's tracts were produced. ${ }^{42}$ Could they all have found a customer? And even so, has each copy been read? The answer is, of course, no. As the bibliographer Hugh Amory pithily said: "most printed books have never been read." 43 In the same vain, when the early 16 th-century emperor Maximilian I introduced print in his chancellery, he ordered draft versions to no longer be crossed out or erased but stored. ${ }^{44}$ Having shelves and shelves of print material became in itself a statement of power and truth. Even today, dissertations are written only to be printed and placed on a library shelf, its only effective power, throughout the years, reduced to bend the shelf ever so slightly. ${ }^{45}$ In this sense, it is true that for print, the medium is the message. ${ }^{46}$

In the digital world, transmitting a text is no effort, and because of the many components required, the medium itself is hardly fixed. Indeed, the digital world has moved only more towards interoperability, where the same file may be presented differently based on the device it is opened on. The one bringing a digital document about is, then, the writer. In fact, in the digital world, we can better speak of users, persons who are readers and writers simultaneously. With the provided interactivity, digital documents hardly invite you to

39 Bourgain, P. “The Circulation of Texts in Manuscript Culture." pp. 140-159 in The Medieval Manuscript Book: Cultural Approaches, edited by M. Van Dussen and M. Johnston, Cambridge: Cambridge University Press, 2015, p. 147.

40 Cf. Dagenais, p. xviii.

41 Pedersen, pp. 31, 34.

42 Finkelstein, p. $5^{2}$.

43 Hugh Amory, as cited by Blair, p. $35^{2}$.

44 Vismann, C. Files. Translated by G. Winthrop-Young. Stanford: Stanford University Press, 2008, p. 92.

45 Dunleavy, P. Authoring a PhD: How to Plan, Draft, Write and Finish a Doctoral Thesis or Dissertation. New York: Palgrave Macmillan, 2003, p. 274.

46 McLuhan, pp. 7-21. As John Dagenais rightly points out for the manuscript world: "It is not so much the medium that is the message as it is the process of production." Dagenais, p. 18. 
be a reader merely. For example, people seldom derive joy from merely 'liking' other people's statuses on social media. Rather, people are usually motivated to post a status of their own and receive likes from others. ${ }^{47}$ This episteme places stress on notions of curation and erudition since it is tempting, from a digital point of view, to merely offer the evidence (all the evidence) and let the user decide for themselves what to do with.

The different emphasis on reading, medium, or writing also explains how the power dynamic of text production is different in each world, that is, who the gatekeepers are. In the manuscript world, it is society as a whole that decides the allowable and the not-allowable by the cumulative effect of copying or neglecting to copy texts. This makes for a decentralized form of authority. ${ }^{48}$ Not so for the print world, where, it seems, everything is held together by commercial forces. When we consider the models of (printed) book history by Darnton and by Adams and Barker, we notice how both allow a connection between author and reader through a closed system, by the mediation of publishers, printers, shippers, and booksellers. ${ }^{49}$ The mere fact that they could draw up models like this shows the integrated nature of book publishing in the print world. When a similar model would be drawn up of the manuscript world or digital world, it would be a lot more busy and not as circular as it is for the print world. For, there is in the digital world little standing in the way for people to write and publish. Gatekeepers in this world are the software companies who set the technical limitations of what is possible but they are in this sense much further away from the actual production of texts than publishers are in the print world.

\subsubsection{Society}

These actors together also bring about institutions of authority at the societal level, irreducible to one or the other actor but nonetheless influential.

The authority of a canon is noticeably different among the worlds. In the manuscript world, a canon builds up slowly but democratically, as each voice can be barely controlled. A manuscript canon comes close to a Darwinian

47 A particularly good example is the rise of fan-fiction in the digital world. See Lindgren Leavenworth, M. "Paratextual Navigation as a Research Method: Fan Fiction Archives and Reader Instructions." pp. $5^{1-71}$ in Research Methods for Reading Digital Data in the Digital Humanities, edited by G. Griffin and M. Hayler. Edinburgh: Edinburgh University Press, 2016.

48 Johnston and Van Dussen, pp. 9-12.

49 Darnton, R. "What Is the History of Books?" pp. 65-83 in Daedalus 111, no. 3 (1982); Adams, T.R., and N. Barker. "A New Model for the Study of the Book." pp. 5-44 in A Potencie of Life: Books in Society, edited by N. Barker. London: British Library, 1993. 
system of natural selection; those texts deemed valuable enough are copied by readers, while those which are not are not copied and invariably go extinct. How popular a text is can literally be measured by its 'population,' the number of copies in which it survives. ${ }^{50}$ What the print world inherits is the slow rate at which canon is made and developed. This is not exactly because readers take a long time to sort out classic from rubbish, but more so because the production of a print publication is a time consuming endeavor. Print publications are an all-or-nothing deal; once it is committed to print, there is little anyone can do. The process of writing, editing, correcting, and finally typesetting is, therefore, a deliberately drawn out process. Once everything is set to go, the publisher can 'game the system of natural selection' by all of a sudden putting out a population of any number of copies. Since this is solely the publisher's decision, the canon is overtly dictated. Readers' preference can only sway publishers' decisions in a secondary sense, by either leaving a publisher with large stock or buying out the stock so fast that the publisher is moved to make another print run. In all of this, with publishers and the demanding process of publishing as gatekeepers, the voices of authors that make it into the canon are subject to selection. ${ }^{51}$ In China, where printing was mostly done with woodblocks, it had an on-demand nature, making the canon produced in that print world much more like a canon in a manuscript world. ${ }^{52}$

Lastly, in the digital world, a canon is formed and changed fast. In fact, the speed of production and dissemination is so fast that often it is not the content that is canonized, but the process. For born-digital, online texts, the process can be a website or a particular writer on a website. For digitized manuscripts, the process can be the digitization technology or the online portal to accessing the photos. Especially in the case of digitized documents, which originally belonged to either the manuscript or the print world, the worth of one artifact can be hard to judge. Its context is missing, both subject-wise and popularity. Whether a book sold a hundred or a hundred thousand copies, both will likely be represented digitally in one document each, and different editions or printruns of the same book are often overlooked in the digital world. ${ }^{53}$ The canon

5o Wogan-Browne, J., N. Watson, A. Taylor, and R. Evans, eds. The Idea of the Vernacular: An Anthology of Middle English Literary Theory 1280-1520. Exeter: University of Exeter Press, 1999, pp. 4-5.

$51 \quad$ Cf. Mandell, p. 91.

52 Chia, L., and H. De Weerdt. "Introduction." pp. 1-32 in Knowledge and Text Production in an Age of Print: China, 900-140o, edited by L. Chia and H. De Weerdt. Leiden: Brill, 2011, pp. 14-15; Blair, pp. 351, 355 .

53 Patten, E., and J. McElligot, eds. The Perils of Print Culture: Book, Print and Publishing History in Theory and Practice. London: Palgrave Macmillan, 2014, p. 13; Weiss, p. 91. 
is subtly dictated, indicating that the voices are seemingly free but actually are within processes of control. For example, terms and conditions may suspend users from participation, and algorithms can decide whether to show or suppress the content.

\subsubsection{Worldview}

We come to the highest, most abstract level of authorities of delimitationreality and truth - which operate on the worldview level. In effect, these notions are consequences of the previous authorities but are worth mentioning separately because of their saying power. In terms of reality, the difference between the worlds is conjunctive with Baudrillard's division of "a universe of natural laws to a universe of force and tensions of force, today to a universe of structures and binary oppositions." ${ }^{54}$ We may say that a manuscript is reality-making, a printed publication is reality-stating, and a digital document is reality-replacing (i.e., hyperreality). In a manuscript world, the worldmaking potential is bound up with readers, who need to decide what to read. In order to read, they need to copy a text. It is the physical manifestation of ink on paper that makes the reality of the argumentations of the texts, the culture that these texts constitute and shape. With every act of copying, the reality of this culture, this worldview, is reified. In a print world, it is also the act of printing the black ink on the white paper that reifies the culture, but, as noted before, it is not really up to the readers to decide what is committed to print. Rather, the gatekeepers are publishers, standing above society at large, dictating to it what ought to be considered part of the culture and what not. In the digital world, it is not the commitment of ink on paper that reifies a worldview. In its aspect of reality-making, the digital world largely relies on encoding the "real world" (manuscript and print world) into zeros and ones. Because the choice is only between zero and one, the digital world's reality is one of either: existing truly or not existing at all, indicating that digital documents are often hailed as 'larger-than-life.' In this way, the digital surrogate somehow becomes a better version of the real world object and can, therefore, supposedly rightfully, outright replace the real world object. ${ }^{55}$

Similarly, for truth, the manuscript world can be called a pre-truth era, where truth is organically established through the many permutations of readers copying texts and, thereby, selecting the argumentations that are considered truthful. Therefore, the print world can simply be called a truth era, where

Baudrillard, J. Simulations. Translated by P. Foss, P. Patton, and P. Beitchman. Semiotext[e], 1983, p. 103 . 
the modernist ideal—of there being only one truth that may be forcefully affirmed - is in effect. Any other expression is deemed corrupt. ${ }^{56}$ Meanwhile, the digital world is a post-truth era, the truth not being construed by what you receive but more so by what you tell others. As Baudrillard cites Nietzsche: "Down with all hypotheses that have allowed the belief in a true world." ${ }^{57}$

\subsection{Grids of Specification}

Lastly, we have the grids of specification. For our purpose, we may subdivide the relevant notions under the headers of possession, engagement, and product.

\subsubsection{Possession}

Under the header of possession, we can discuss what the monetized product is for each world. As may be expected, this has a close relation with the stakeholders. In the manuscript world, the product that can be profitably exploited is the codex, the physical object in which the text, any text, is contained. A codex is typically produced with such high quality as to outlive its first user. ${ }^{58}$ For print, it is the text itself. Codices can be mass produced and, therefore, profit comes from selling an ever larger number of copies. The text itself is a scarce good in a print world, which is why the publishing industry has almost always lobbied for copyright laws. The text as the monetized product for the print world can be gleaned from Walter Ong's view, who argues that "alphabet letterpress printing, in which each letter was cast on a separate piece of metal, or type, marked a psychological breakthrough of the first order. It embedded the word itself deeply in the manufacturing process and made it into a kind of commodity." 59 The mise-en-page, however, is important too, unlike with digital documents. ${ }^{60}$ For example, this allows for the page number to become a dominant feature of print publications, from which derives the possibility to reliably and accurately refer to the text. ${ }^{61}$ In the digital world, it is yet another thing altogether-the monetized product is the user itself. In abundance and easy to reproduce are both textual content and textual manifestation, whereas in scarce supply is the user engagement.

$5^{6}$ Ong, p. 128, Mahdi, M. "From the Manuscript Age to the Age of Printed Books." pp. 127-142 in The History of the Book in the Middle East, edited by G. Roper. Surrey: Ashgate, 2013, p. 131.

57 Baudrillard, p. 115 .

$5^{8}$ Johnston and Van Dussen, p. 7.

59 Ong, p. 116. Cf. Ong, p. 129.

6o Nunberg, G. "The Places of Books in the Age of Electronic Reproduction." pp. 13-37 in Representations 42 (1993), p. 18.

61 Sutherland, "Being Critical," p. 22. 
Inherent to this is the value of each individual artifact. In a manuscript world, an artifact is worth a lot, as it itself is the exploitable, scarce good. In the print world, a single artifact represents some value, as its sale is still what gives the publishers profit, be it only the aggregate sale of many copies. Parallel to this runs the intellectual value, the difference of which John Dagenais has aptly described when he asked the rhetorical question "What is the intellectual value (and cultural significance) of taking a text that was written and read in a variety of forms in numerous medieval manuscripts and transforming it into a single printed book?"62 I use 'parallel' because I think we can equally ask for the monetary value in exchanging one for the other, as is done through critical editing, and the rhetorical value would be retained. There is an increasing trivialization of the written word, from oral to manuscript to print to digital, because, as Jan-Dirk Müller aptly notes: "Technical reproduction might have seemed at first a chance to preserve writing for everyone and for all time, but it abolished traditional selection mechanisms that established what is worth knowing and preserving." 63

In the digital world, a single artifact represents consequently very little value. Without engagement, its existence is quite meaningless as far as the digital world is concerned. Engagement can only be driven, as BnF's former director Jean-Noël Jeanneney forcefully points out, if a repository is curated: "An indeterminate, disorganized, unclassified, uninventoried profusion is of little interest,"64 he says. As the digital world and its episteme move forward, Jeanneney notes that we are already up against it: "The enemy is clear," he says, "massive amounts of disorganized information." ${ }^{65}$ This perspective is refreshing, since it seems that digital platforms are often built on the premise that if we build, they will come. ${ }^{66}$

To complete the grids of specification concerning the possession of artifacts, we can look at ownership from the points of view of the producer and consumer. A manuscript is privately owned and privately made; a print publication is privately owned but corporately made. A digital document, finally,

62 Dagenais, p. xvi.

63 Müller, J.D. "The Body of the Book: The Media Transition from Manuscript to Print." pp. 32-44 in Materialities of Communication, edited by H.U. Gumbrecht and K.L. Pfeiffer, Stanford: Stanford University Press, 1994, p. 33.

64 Jeanneney, J.-N. Google and the Myth of Universal Knowledge: A View from Europe. Translated by T.L. Fagan. Chicago: The University of Chicago Press, 2007, p. 5 .

65 Jeanneney, p. 70.

66 Andrew Weiss notes, perhaps more wishfully than factually, that libraries are changing from a 'just in case' strategy to a 'just in time' strategy, in which a resource is acquired only after a demand from a patron, Weiss, p. 130. 
is in principle corporately owned and corporately made. For manuscripts, this may be rather obvious; even when texts are copied by a professional scribe and even when such is done without prior commissioning, the production still has a private element to it - in the sense that it can inherently be made according to specific demands, and this would not at all be out of the ordinary. Once the production is completed, the result, the codex, belongs squarely to the readers, who can do with it whatever they want. A new binding, or reshuffling of the text, writing in the margins: none of these codex-altering actions would be considered strange, and that is because it is the prerogative of the owner of the codex to do with it what they want. For print publications, such authority is shared between the reader and the publishing industry, since the ownership can indeed be said to belong to the reader, but the production belongs explicitly and exclusively to the conglomerate of publishers, printers, shippers, and booksellers. From this, we can predict that it could be frowned upon for a reader to do alterations to the artifact. "I don't annotate my books. Personally, I think that defiles the printed page," admits an advocate for digital documents. ${ }^{67}$ We may note a process of more and more ownership towards the publishers over the centuries. Whereas before, books could be published in fascicles, and it was normal, expected, of the reader to bind their books to their liking. Today, books are often in paperback format, held together by glue, making it nearly impossible to do anything major to the book without fundamentally breaking it. The digital documents are, in this sense, the logical conclusion of a shift towards corporate ownership. Any digital document only exists and can only be fruitfully used through a combination of hardware and software. Software is more and more provided on a subscription basis, making users rely on corporations to access digital documents. Their user agreements can legally lock anyone out of their own work if users transgress a set of arbitrary rules. The continued development of software and hardware can make a current digital document go out of date in a matter of years with no possibility of further access. Their aggressive push to convince users to physically transfer files from local computers to their corporate servers ('the cloud') means that once those servers go offline, users can no longer access their files. This process is not only happening at the consumer level. With the arrival of large collections of digitized resources in the possession of corporations, such as Brill's Middle Eastern Manuscripts Online (combined current cost: $\$ 38,370$ ) or Gale's Eighteenth Century Collections Online (cost can be more than $\$ 300,000$,

67 Merkoski, p. 16. 
excluding an annual fee), this ought to be an acute issue for academia across the board. 68

\subsubsection{Engagement}

We engage with artifacts in several ways. First, we can consider the kind of activity in each world. Manuscripts can be said to be active, in that the medium responds to the user, with the user being both writer and reader, sender and receiver, écriture and ré-écriture. ${ }^{69}$ The medium, the surface of the folios of codices, change according to the actions of writers and readers. For printed publications, the medium only responds to the sender: the author in combination with the publisher. The reader is confronted with the end result and can only react. The print world is, therefore, reactive. In contrast, the digital world is interactive. Although the medium is presented as an end result, users can do all kinds of things with it to change it. In other words, users respond to a medium that responds back. This makes the act of reading quite different in each world. To exaggerate the differences, we can say that manuscripts are read charitably and with great engagement and focus. Print publications are read docile and acceptant. And digital documents are read egotistical and only for a specific personal purpose. Often, digital documents are entered not from the beginning of the text or the beginning of a chapter, but at the very instance where a keyword search has brought the reader. ${ }^{70}$

That, in principle, this is so can be seen from the different ways readers can respond. In manuscripts, readers can respond by writing in the margins. For printed publications, this is possible but uncommon. Somehow, it seems that the ultra-white of the pages and the crispness of the printed black text resists handwritten comments. Walter Ong observed:71

There is no way directly to refute a text. After absolutely total and devastating refutation, it says exactly the same thing as before. This is one reason why 'the book says' is popularly tantamount to 'it is true.'

68 Patten, McElligott, p. 14.

69 Dagenais, p. 21; Poirion, D. "Ecriture et Ré-Écriture Au Moyen Âge." pp. 109-118 in Littérature 41 (1941); Cerquiglini, B. Éloge de la variante. Paris: Éd. du Seuil, 1989.

70 Patten, McElligott, p. 14; Sentilles, R.M. "Toiling in the Archives of Cyberspace." pp. 136-156 in Archive Stories: Facts, Fictions, and the Writing of History, edited by A. Burton. Durham: Duke University Press, 2005; Eggert, p. 67; Jeanneney, p. 68.

Ong, p. 78 . 
Ong alludes here to the idea that to refute a printed book, one needs to publish and print another book. Otherwise, it will not be on the same footing. To make counter arguments in writing, in the margin of one's personal copy, is rather pointless, as you know that there are hundreds, perhaps thousands of other copies without your marginal comments, and future copies will be based off of the files of the publisher, and not your commented-upon copy.

Meanwhile, digital documents allow users to write directly in the document itself. This constitutes different kind of conversations. In the manuscript world, we witness dialogues between the body of the text, the author, and the margin, the reader. ${ }^{72}$ It is as though there is a person-to-person conversation going on. ${ }^{73}$ This stipulates a style that is determined by building on earlier texts. It is normal for a text in the manuscript world to consist largely of copies of other texts, with only a small percentage of alterations, additions, and deletions. In printed texts, we have monologues, with the author telling the reader exactly how it is, which perhaps partly explains why the analytical framework of the author's intentions was dominant for most of the modern era. ${ }^{74}$ Newspapers are a particularly good example of this, often filling the entire space of the page with walls of justified text. In case there is not enough text, newspapers rather insert 'fillers' than leave the space blank. ${ }^{75} \mathrm{Of}$ course, this does not mean there is not a trace of dialogue in the print world. There is ${ }^{76}$ just as much as the author can long be dead while readers still come up with new responses to his or her work. ${ }^{77}$ But the motor that drives the print world does not fuel on such readers, only on genius authors. ${ }^{78}$ Tim Ingold sees this as a result of the mechanization of text production. Likening sign language to other manual gestures, he says that "so long as the movement of the hand leaves an immediate trace on the page, there is no great difference between looking at signed words and looking at written ones. ${ }^{79}$ Manuscripts, according to him, are inhabited with living voices, whereas "the voices of the past are eliminated from the printed text." ${ }^{80}$ Indeed, it is a common complaint that the printed text 'do not talk

\footnotetext{
72 Ong, p. 130.

73 Pedersen, p. 35; Chia and De Weerdt, "Introduction," p. 18; Lit, L.W.C. van. "Islam Felsefesi ve Bilginin Dolayımi: El Yazmaları Üzerinden Yüz Yüze Sohbet.” pp. 78-81 in Sabah Ülkesi $5^{2}(2017)$.

74 Finkelstein, p. 8o.

75 Ong, p. 130.

76 Finkelstein, p. 108.

77 Barthes, R. "The Death of the Author." Aspen 5-6 (1967).

78 Wogan-Browne et al., p. 6; Ingold, T. Lines: A Brief History. London: Routledge, 2007, p. 24.

79 Ingold, p. 28. Cf. pp. 93, 127, 139.

8 o Ingold, p. 24.
} 
back'. ${ }^{81}$ It is no surprise that the style of printed text is often determined by the adage 'say it once, say it well.'

In the digital world, I think there is essentially only soliloquy, a dialogue strictly with oneself. ${ }^{82}$ In this sense, digital writing is the conclusion to what Walter Ong has perceived as a consequence of the separation of knower and known, namely that "writing makes possible increasingly articulate introspectivity." 83 This aspect of the digital world may be surprising, as it seems exactly the 'social' aspect that is often developed and highlighted. ${ }^{84}$ But it is a consequence of the 'silofication' of the digital world, which separates each document or a bunch of documents from others without a clear context to place them in. ${ }^{85}$ As far as there is interaction between people, this is primarily exploited to try something out and use the feedback to try something better since any act of writing has a trivial cost and writers can act as though they are their own publisher. ${ }^{86}$ As such, it combines aspects of the manuscript and the print world: from the former, it takes the evolutive character of texts; from the latter, the one-directional decision making.

\subsubsection{Product}

There are four more notions to discuss on the level of the product itself. One is the end result of the product. A manuscript codex produces a process in flux. What I mean by that is that the entire production process can be witnessed, down to the mistakes that were crossed out and corrected, and often, it can generally be established what the order of that process was. ${ }^{87}$ In chanceries, rather than throwing out drafts, they were crossed out. ${ }^{88}$ In addition, a manuscript's result is open-ended; a reader is invited to continue the process by adding text (or subtracting by crossing out). Tim Ingold provides us a good image of how a manuscript works: "the surface of the page [is] like a country in which one finds one's way about, following the letters and words as the traveler follows footsteps or waymarkers in the terrain." 89

81 E.g. Blatty, W.P. The Exorcist: A Novel. New York: HarperCollins, 2011 [1971], pp. 36-37.

82 Kathryn Sutherland hints at it. Sutherland, "Being Critical," p. 24.

83 Ong, p. 103. Cf. McLuhan, p. 32.

84 Merkoski, p. xii; Mandell, p. 155.

85 McGann, p. 30. Weiss, p. 28.

86 Cf. Müller; Finkelstein, p. 120.

87 Johnston and Van Dussen, pp. 4-6; Dagenais, p. 17. Dagenais also says that "the handwritten text as product resembles the mechanically reproduced book; the process of its creation mimics the unique, occasional nature of oral tradition and oral performance." It is an interesting observation but I cannot do anything with it in my own analysis here.

88 Vismann, p. 26.

89 Ingold, pp. 24-26. 
A printed publication, by contrast, presents the reader not with a process, but with a result. ${ }^{90}$ Exactly how the text visible on paper came to be is entirely unclear from a mere examination of the page, which is why 'the' publication year is hailed as an important metric. ${ }^{91}$ Ingold likens print publications to cartographic maps: "Had it not been for the journeys of travelers, and the knowledge they brought back, it could not have been made. The map itself, however, bears no testimony to these journeys." ${ }^{\prime 2}$ Further, this is a fixed end result as it cannot be changed. Anything added to it will stand out as handwriting and, therefore, not part of the print world. If it does come out in the print world, it will be in a separate publication, remaining largely harmless to the original text. ${ }^{93}$ This gives it a sense of veracity, which can be deceiving. ${ }^{94}$ Digital documents also present the user with an end result, with no immediate way of knowing how the elements of the document came to look like they do. However, digital documents are in flux, as any reader can alter them without leaving any trace of such alteration. A next user would simply assume that the altered version is the actual end result of that digital document.

This difference in the end result tells us something about the different perceptions of the fixity of the product. An open-ended manuscript is known to shift and, therefore, not expected to be fixed. It is good to point out that this expected shifting can take different forms across different cultural zones. Notably, in the Islamic world, there is a certain reverence for authorial intent, and rarely do people take the liberty to overtly change the wording of a previous text. ${ }^{95}$ In medieval Europe, however, such arbitrary interventions were commonly accepted. ${ }^{96}$ If two manuscript copies of the same text show a difference, this ought to be considered a variant, not an error, as that is what makes them manuscripts and not a printed book. ${ }^{97}$ When scholars want to transfer a text from the manuscript world to the print world, they have, all too often, defined their approach using the print world's terms, which proposes an illusion of being fixed, as though set in stone-typographic fixity, as Elizabeth Eisenstein has

\footnotetext{
$90 \quad$ Ong, p. 129.

91 Patten, McElligott, p. 12.

92 Ingold, p. 24.

93 Mandell, pp. 155, 174.

94 This counts too for the Far East, see Chia and De Weerdt, "Introduction," p. 12.

95 Lit, L.W.C. van. "Commentary and Commentary Tradition: The Basic Terms for Understanding Islamic Intellectual History." pp. 3-26 in MIDEO 32 (2017).

96 Nichols, S.G. "What Is a Manuscript Culture? Technologies of the Manuscript Matrix." pp. 34-59 in The Medieval Manuscript Book: Cultural Approaches, edited by M. Van Dussen and M. Johnston, Cambridge: Cambridge University Press, 2015, p. 35.

Dagenais, p. 18.
} 
called it. ${ }^{98}$ This is the proposal of the Lachmannian critical edition. ${ }^{99}$ The use of such an edition, neglecting the manuscripts it emanated from, is seemingly taken for granted. ${ }^{100}$ This counts as much for the 2oth century as it does for the 1oth, as long as it is a print world in which people operate. Thus, the Chinese ruler Mingzong demanded that even manuscript copies should be based on the printed versions of those texts, lest there be 'interpolation.' ${ }^{101}$ The reality is, however, that even for born-print texts, differences between editions can exist, and even within one edition, copies can show variance due to the changes made during the process of printing. ${ }^{102}$ Walter Ong notes the difference between the manuscript and print world: "Writing moves words from the sound world to a world of visual space, but print locks words into position in this space." ${ }^{103} \mathrm{He}$ notes a similar difference in the mise-en-page: "Chirographic control of space tends to be ornamental, ornate, as in calligraphy. Typographic control typically impresses more by its tidiness and inevitability".104 Digital documents have an even bigger illusion of fixity since their existence relies on zeros and ones, and it therefore is, or it is not. ${ }^{105}$ But what makes this an illusion is that the string of zeros and ones can at any time be changed. This is sometimes proposed as a desirable feature, ${ }^{106}$ without taking into account the uncertainty this fosters. For example, documents can be silently withdrawn, and users can be banned without the possibility to appeal. ${ }^{107}$ More importantly, since the supporting technology — both hardware and software — undergo a seemingly inexorable

98 Eisenstein, E. The Printing Press as an Agent of Change: Communications and Cultural Transformations in Early-Modern Europe. 2 vols. Cambridge: Cambridge University Press, 1979, vol. 1, p. 116.

99 Kleinlogel, A. "Variants and Invariants: The Logics of Manuscript Tradition." pp. 259-268 in Theoretical Approaches to the Transmission and Edition of Oriental Manuscripts, edited by J. Pfeiffer and M. Kropp. Beirut: Ergon Verlag, 2007.

100 Dagenais, pp. 112, 114; Sutherland, "Being Critical," p. 25; Nichols, S.G. "What Is a Manuscript Culture," pp. 34-35.

101 Chia and De Weerdt, "Introduction," p. 24.

102 Lerer, S. "Bibliographical Theory and the Textuality of the Codex: Toward a History of the Premodern Book." pp. 17-33 in The Medieval Manuscript Book: Cultural Approaches, edited by M. Van Dussen and M. Johnston, Cambridge: Cambridge University Press, 2015, p. 18; Finkelstein, p. 20. Just consider the jungle of differences in the printed work Vilette by Charlotte Brontë, described in Sutherland, "Being Critical," p. 16.

103 Ong, p. 119.

104 Ong, p. 120.

105 Baudrillard, p. 117.

106 Eggert, p. 64.

107 Jeanneney, p. 48. 
change, the sustainability of digital documents in, say, one or two generations, is an acute problem which has been offered very little attention. ${ }^{108}$ Manuscript Terminology

To better understand some of the differences between the manuscript world and the print world, and to see the previously discussed theoretical consequences played out in reality, let us compare two books that are each other's counterparts, one representing the manuscript world, the other the print world. For this purpose, we can make excellent use of A Dictionary of English Manuscript Terminology $1450-2000$ by Peter Beal and ABC for Book Collectors by John Carter and Nicolas Barker. Beal no less than opens his preface by saying: "This dictionary was originally inspired by John Carter's $A B C$ for Book Collectors (first published in 1952). What he had done for books it seemed reasonable to do for manuscripts." 109 To compare the two books is, therefore, baked into the very plan of the books. As Beal's book was published in 2008, it seems good to somehow bridge the fifty-year gap between the two publications. To make the comparison as fair as possible, we shall avail ourselves of $A B C$ 's 8 th edition, which was prepared by Nicolas Barker in 2004 and corrected in 2006 by Raymond Williams.

Both books are a collection of entries, and 158 of them bear identical titles in both books. A majority of them were either exactly alike or did not reveal significant differences between the manuscript and print world. Twenty six of them, however, laid bare the theoretical differences previously discussed. I group these entries under three themes, concerning (1) the difficulties of transitioning from manuscript world to print world, (2) the craft of placing text on paper, especially regarding its decoration, and (3) the qualities desired by buyers.

\subsection{Manuscript Practices in a Print World}

Features typical of manuscripts are all of a sudden undesirable in printed works. ABBREVIATIONs, for example, were very common in manuscripts. Writing things by hand is labor intensive, and any shortcut is welcome.

108 Jeanneney, pp. 63-64; McGann, p. 27. He notes that exactly our classic fields of "philology and textual criticism can help us gain that knowledge."

109 Beal, P. A Dictionary of English Manuscript Terminology 1450-20oo. Oxford: Oxford University Press, 2008, p. viii. 
Abbreviations provide such a shortcut, all the more because a hand governing a pen offers a convenient and flexible tool to write, for example, " $\&$ " instead of "et." This flexibility is lost in the print world, when the typesetter has a limited number of type sorts to set any text. If anywhere the personal touch of a copyist is lost against the uniformity of typesetting, it is with abbreviations. Thus, a manuscript may read "opa" with a dash through the bar of the $p$, by which is meant the Latin word opera (works). In printed works, this word is often typeset simply as "opera" or, in the case of some critical editions, as "op[er]a". As may be clear from seeing "opa" restored to its former glory, in the digital world we are better able to encapsulate such glyphs. The important difference between "opa" and "opera" is that in the latter case, spelling is dictated by the producers of the publication.

A similar notion can be witnessed in the production of ALMANACs. In the manuscript world, Beal points out that almanacs often had "blank pages or spaces for owners' personal entries to be made by hand."110 There is, then, a notion of generosity and inclusion of the reader. For printed almanacs, in contrast, we read that they were "protected by jealously guarded patents,"111 that is, they are marked by exclusion. A similar tension is witnessed in the entries on SAM MELBAND. Beal, writing about manuscripts, simply remarks that one volume containing different works is a known phenomenon. Carter, writing about printed works, notes the undesirability of this, and the frequent destruction of the binding and separation of the works; whereas texts live inclusively in the manuscript world, they generate exclusivity in the print world.

In this regard, the entries for ANonymous authors are relevant too. Beal points out that "a huge number of literary works" are without a known author. ${ }^{112}$ He goes on to describe how the anonymity of the author was of no problem in the manuscript world. Carter, meanwhile, mentions that "a book by an unidentified author is harder to sell."113 What was a neutral phenomenon in the manuscript world, becomes contentious in the print world. This is, I would argue, because of the shift of the focus from the readers to the medium.

We can witness a shift of power from the copyist-reader to the publishermedium. Whereas manuscripts have a COLOPHON at the end, describing mostly the context of the commissioning reader, printed works instead describe the context of the publishing author. Moreover, the print world phased

\footnotetext{
110 Beal, p. 14.

111 Carter, J., and N. Barker. ABC for Book Collectors. 8th ed. London: Oak Knoll Press, 2004 [Or. 1952], p. 23 .

112 Beal, p. 17.

113 Carter, p. 25.
} 
out the colophon at the end and replaced it with a TITLE PAGE at the beginning. Both the change in contents and the change in place show an affirmation of power by the publisher and related companies. One such change of contents is the ritualization of the date of issue. In the manuscript world, texts simply emanated from the author by the demand of readers for a copy, which made it important to mention the date of copy in the colophon. In the print world, the notion of PUBLICATION became all-important: "the offering of the book, for sale, to the public."114 Thus, the date of publication is included on the title page. The very existence of a text is, furthermore, guaranteed much differently. For manuscripts, it is the general agreement among a body of readers that a text is worthy to be saved and copied. For printed works, it is the publishing industry who makes this decision. It is not without reason that even though the term IMPRIMATUR can be found in both Beal's and Carter's book, it nevertheless only applies to printed books, as a synthetic replacement for the consensusprocess of the manuscript world.

It is, finally, striking that some terms become mere homonyms. FInGERPRINT, for example, refers in the manuscript world simply to the imprint of a human finger, left behind in manuscripts because of spilled ink. In the print world, it relates to a process to distinguish differences in typesetting by "comparison of several letters in adjacent lines." the manuscript world is a private message written by one person to another; whereas, in the print world it refers to the pieces of metal that can be typeset. In both cases, the meaning has shifted away from an individuating aspect of the copyist to an identifying aspect of the publisher.

\section{2 $\quad$ Fear of Voiding or Fear of the Void}

Horror vacui, or fear of the void, is a phenomenon well-known to any manuscript culture. As the great medieval litterateur al-Jāhiz says, "a black space is better for it than a white one."116 Marginal notes are the bread and butter of the manuscript world. All of a sudden, this becomes different in the print world, where there is a fear of voiding: it is exactly the 'staining' of the pages, including the white space, that is avoided. We see this reflected in several entries from Beal's and Carter's books. ERrATA provides a good starting point. Whereas manuscripts would be checked for accuracy and corrections would be made in the margin directly at the offending place, corrections to printed works would

\footnotetext{
114 Carter, p. 180.

115 Carter, p. 103.

116 As translated by F. Rosenthal in The Technique and Approach of Muslim Scholarship. Rome: Pontificium Institutum Biblicum, 1947, p. 6.
} 
be made on a separate piece of paper and either bound with the book or simply inserted as a loose sheet. The offending page remains untouched. The term COLLATION, therefore, means something entirely different in the two worlds. Beal describes it as the process of checking the text of one copy against another, whereas Carter describes it as the process of checking the division of pages into quires of one copy against another. For manuscripts, then, the emphasis is on how the copyist rendered the text, whereas, for printed works, the emphasis is on how the publisher and printer rendered the volume. Furthermore, while the collation for manuscripts is, in a certain sense, a neutral process, leaving open the correctness of a reading, the collation of printed works is to judge the completeness of a copy. This completeness, of course, is about how the book was produced, not whether the full text is available in the volume. This is further reflected in the difference in using the term varianT. For manuscripts, a variant means "a reading in one or more manuscript or printed publications that is different from the one in the particular text under scrutiny."117 For prints, a variant is "to describe a copy or copies of an edition or impression exhibiting some variation, whether of text, title page, illustrations, paper or binding, from another copy or copies of the same edition or impression."118 In other words, while the manuscript world uses the word variant to indicate a difference in contents, the print world uses it to indicate a difference in medium.

HISTORIATED is another good example of the difference in fear. Historiated means that the initial capital is decorated with, properly speaking, a scenery but any decoration could work. In the early stage of the print world, such decorations were expected to be done, and the typesetter would only print a GUIDE LETTER, a small letter to indicate the letter which the decorator should draw and decorate. It seems that quickly these letters were left standing on their own and no decoration was applied; whereas manuscripts would be labored over for hours to decorate, printed works would be left untouched.

The term DECORATION itself provides for a striking comparison. Whereas Beal speaks of the decoration of the text on the page, Carter defines decoration in terms of the embellishment of the volume, the book as a whole, especially the covers and the binding. The 'void' of the white space on the pages is left alone, perhaps out of a fear of voiding the pristine quality of the copy of the book. No other aspect of manuscript and print production shows this difference more starkly than ILLUMINATION and GILDING. Whereas for manuscripts this means the use of gold leaf either to write out text or to embellish it, for print works it means the decoration of a book's edges when closed flat. It is

117 Beal, p. 428.

118 Carter, p. 227. 
as though the page itself is the domain of the publishing industry, which is not to be messed with, and so the gilding literally falls off the pages!

\subsection{Moldy Manuscript or Pristine Print}

Lastly, in their description of manuscripts and printed works, Beal and Carter demonstrate that a different aesthetic is at work. This speaks firstly from Beal's stereotypes of the greatest lovers of manuscripts and printed works, respectively. He uses John Earle's 1620s description of a manuscript collector "as a wrinkled old man who 'loves all things ... the better for being mouldie and wormeaten."'119 A collector of printed works, meanwhile, is described as someone "who is devoted to acquiring or assembling a collection of books or manuscripts, generally as artifacts in their finished form." ${ }^{120}$ The contrast of the two is not so clear at first, but the crux lies in the term 'finished form.' Whereas manuscript lovers do not mind a good wORMHOLE, Beal informs us that such is "universally reviled by librarians and book collectors." ${ }^{121}$ Finished form, then, is a synonym here for pristine. Carter literally glosses 'finished product' with "the product in its first, pristine form." 122 'Pristine' is a good word to describe the desired aesthetic of a book, for it hints at both an unspoiled state, clean and crisp, as well as an original, untampered state. The two aspects of pristine sometimes conflict with one another. "The greatly increased respect for original state among collectors," says Carter, "has tended to reduce to the minimum the amount of tampering with even battered copies." ${ }^{123}$ Clearly, then, whereas for manuscripts the wear and tear caused by readers is a desirable quality, for printed books, it is the original state of publication that is sought out.

Other forms of tampering or wear and tear are similarly different. Under the entry INSCRIPTIONS, Beal describes in relatively favorable terms how manuscripts often have additional handwritten comments. Carter, on the other hand, speaks of them in terms of "something of a defacement."124 Those copies from a library (that is, EX-LIBRARY) that show such traces are valued by Beal as "obviously valuable evidence of provenance,"125 whereas Carter writes that such "traces are regarded with lively disfavor by most experienced collectors and with contempt by the fastidious." ${ }^{126}$ The entire BINDING of

\footnotetext{
119 Beal, p. 19.

120 Beal, p. 8o.

121 Beal, p. 441.

122 Carter, p. 181.

123 Carter, p. 190.

124 Carter, p. 131.

125 Beal, p. 148.

126 Carter, p. 96.
} 
a volume is itself subject of aesthetic difference. Manuscripts, Beal writes, "are likely to be in bindings supplied by subsequent owners, reflecting their individual tastes or circumstances."127 I did not find a similar comment about bindings of printed works in Carter's book, but the presence of an entry called 'DeCKLE-FetishisM', "The over-zealous, undiscriminating passion for uncut edges in books which were intended to have their edges cut"128 should say enough.

The difference in aesthetic is, lastly, rather splendidly demonstrated in the differences between the entries on FACSIMILE. Beal has a rather tame and neutral description of what a facsimile is: "an exact copy [...] imitating in every detail the original physical artifact."129 Given what we know of the manuscript world, though, I think we may surmise that a facsimile is something that is quite desirable, a dream of any copyist. We may think of the many facsimiles (in the form of printed and bound photos) in use by scholars of famous manuscripts, allowing us to examine the manuscript 'as it is' without being on site. In the print world, according to Carter, "it figures frequently in the nightmares of collectors, [and] causes booksellers more trouble than almost any other factor in their business." 130 The reason for this is quite clear. "An exact copy is a menacing thing to those who pursue originals." ${ }^{131}$ I think demand drives supply here. The apparently real market of forgery of rare books shows how desperate the craving for pristine copies is. Seeing that a book is mechanically produced, what would be the disadvantage of having a mechanical reproduction? The text contained in it is presumably the same so the reading experience will be about equal. The problem becomes real if it is the medium that is central to the print world, since it is exactly the medium that is being tampered with in the case of a facsimile. Dismissing a facsimile is neither about the authorial intent nor the readers' response, but the medium itself and the authority it derives from its publisher. A facsimile steps into that space of the medium but without authorization and, as such, it chips away at the very epistemology of the print world. Book collectors, it seems to me, intuitively understand this; hence, their outrage.

\footnotetext{
127 Beal, p. 39 .

128 Carter, p. 79.

129 Beal, p. 150.

130 Carter, p. 98.

131 Carter, p. 99.
} 

Clear?

Let us make a concrete comparison between the worlds of print and digital. Again, I merely want to point out some notable differences, mostly having to do with their assumed epistemology since that is what largely constitutes their world-making potential. I found an excellent couple in Emmy Favilla's $A$ World Without "Whom" and Harold Evans's Do I Make Myself Clear?132 One is a young copy editor at BuzzFeed, the other a veteran editor of The Times and Sunday Times, currently at Reuters. The books are highly comparable, as both provide a writing guide, and both decided to write a guide because so much has changed with the rise of the rivalry between digital writing and printed writing. One defends a way of writing associated with print; the other merrily advances the case for a new way of writing - the way of the internet. They were both published in 2017, drawing, now and then, from the same source material. Whereas the book defending print-writing uses ample examples from the internet, uses the word "listicle" and even includes in the body of the text a URL to a YouTube video, the book defending digital writing all too often shows its reverence for Merriam-Webster Dictionary and the Associated Press Stylebook. What, finally, makes these books clearly a good combination for comparison is that it would be hard to decide which one is which, merely based on the titles. It is $A$ World Without "Whom" which is defending a new way of writing, native to the digital world, which welcomes the disappearance of the word 'whom.' But one could easily imagine it to be the title of the book defending a writing style native to print, bemoaning its disappearance.

\subsection{Word of the Year: 2015 or 2016 ?}

Favilla and Evans have different reasons for writing. In as much as their reasons come together, they are each other's opposite. This can be epitomized by their shared appreciation for the 'Word of the Year' as chosen by the Oxford English Dictionary. Favilla feels vindicated by 2015's word, which was chosen to be, controversially, the "Face with Tears of Joy" emoji. As Favilla puts it: "I mean, what a time to be alive, seriously." ${ }^{33}$ At the same time, she argues herself that an emoji is not a word, and the emojis featured on the cover of her book are purely decorative. This can be understood when we read on the

\footnotetext{
132 I was pointed in this direction by Tom Rachman's review of them in "Writers gonna write" pp. 8-9 in The Times Literary Supplement, no. 5990, January 192018.

133 Favilla, E.J. A World Without “Whom.” London: Bloomsbury, 2017, p. 260.
} 
first page that "this book is about feelings." 134 Emojis do not need a precise definition; as long as they convey a certain feeling or aesthetic, they are warmly welcomed by Favilla. In other words, she is aware that the digital way in which she has been using language supports the idea that texts are supposed to be subjective.

Evans, however, attaches greater value to 2016's Word of the Year, which was 'post-truth.' To him, "we are certainly in the vortex of what's come to be called the post-truth society." ${ }^{\prime 35}$ Evans parses this notion to a figure of speech, that of 'fog.' "Fog everywhere. Fog online and in print,"136 he opens the book. And he finishes the book saying that "The fog that envelops English is not just a question of good taste, style, and aesthetics. It is a moral issue."137 This is because, in Evans's words, "Words have consequences,"138 and he contends that "the oppressive opaqueness of the way much of English is written is one cause for a retreat from reason to assertion."139 The enabler of this opaqueness he finds in "digital social media," which is "an unwitting agent for the mass dissemination of rumor and semi-truth now known as Fake News."140 He concludes that "the consequences of all the propaganda are real,"141 and gives the 2016 US Elections as an example. In other words, Evans is uneasy with a perceived erosion of language's use as a conveyer of truth. In the print way that he has used language for his entire life, the text is supposed to be objective.

The subjective/objective dichotomy is reflected in how I argued that the digital world has the sender (authors) at its core and the print world has the medium (pages). This constitutes a different power dynamic. Thus, Favilla does note OED's 2016 Word of the Year (post-truth) but dismisses it as irrelevant. When it comes to writing, she says that "you can start your sentences however you please, because your stylistic preferences make you you. Also? They're words, not weapons." 142 This is in stark contrast to Evans, who quotes Christine Kenneally for making the point that as a writer, "you are a god in language. You can create. Destroy."143 For Favilla, a single digital text is innocent, whereas Evans attaches great weight to it. Favilla says: "Select the phrasing

\footnotetext{
134 Favilla, p. 1.

135 Evans, H. Do I Make Myself Clear? London: Little, Brown, 2017, p. 194.

136 Evans, p. 4.

137 Evans, p. 347.

138 Evans, p. 3 .

139 Evans, p. 16.

140 Evans, p. 302.

141 Evans, p. 306.

142 Favilla, p. 136.

143 Evans, p. 346.
} 
that gets the intended meaning across in the briefest way. You've got the power here, and I'm confident you'll use it wisely."144 Such a statement betrays a mentality in which one text cannot possibly make a big difference. As for the power that an author does have, they have it as a birthright in the digital epistemology. This shines through in Favilla's book when she says that "artistic license is especially constructive when the internet is the medium."145 This is because digital writing is "often more personal and more plan-languagey."146 If the meaning of words is corrupted along the way then "that's neither sad nor cause for outrage-it's simply reflective of how the word has devolved." ${ }^{147}$ Most telling is the following passage from Favilla's book: ${ }^{148}$

Since we live in an era where we can literally TALK TO THE DICTIONARY, we decided to go straight up to the source and ask what the hell was up.

The passage is followed by an image of a tweet directed at Merriam-Webster, questioning the veracity of a dictionary entry. The tone in the sentence above is purposefully rude, as a joke to contrast the seriousness of doubting the judgment of a respectable publication such as Merriam-Webster Dictionary with the easiness with which one can, nowadays, publicly make known such a doubt. In other words, Merriam-Webster might rule over what is printed on paper, thereby consolidating power through the medium, but in a digital world such power leaks away, since anybody can write back and call into question the very definition of words.

Meanwhile, print epistemology is defended by Evans. It is as though he directly responds to Favilla's rude statement about calling into question dictionaries when he says: "The gatekeepers who scrutinized all entrants to the citadel of print have now been outflanked by os and is in the millions." 149 What can be said in a manuscript world is decided by readers, owing to their decision regarding the texts to be copied. What can be said in a print world is decided by 'gatekeepers' - the publishers and their auxiliaries, through their control over the 'citadel' - the medium of the page. What can be said in a digital world, however, is decided by writers. Each may only be insignificant, but add the millions together, and discourse will gradually move in a certain direction. What we argued for in the theoretical part of this chapter we can now see confirmed

\footnotetext{
144 Favilla, p. 155 .

145 Favilla, p. 1.

146 Favilla, p. 17.

147 Favilla, p. 227.

148 Favilla, p. 84.

149 Evans, p. 197.
} 
in the wild, by Favilla, who affirms that "today everyone is a writer-a bad, unedited, unapologetic writer."150 For those who grew up in a digital world, this is a rather obvious statement, barely worth making. But for a person like Evans, born and raised in the print world, it is a fact he cannot even muster the patience for. Addressing his readers, he says, with misplaced irony: "If you are more into explaining your inner self to the waiting world than in conveying information, stop here and brood on to greatness."151

\subsection{Thinking to Type or Typing to Think? Typewriter versus Text Messages}

The theoretical differences I noted in terms of process and the end product can be seen in the books by Favilla and Evans. Both present one guiding principle that tells a lot about their assumed epistemologies. For Favilla, it is "break any of these rules sooner than say anything outright barbarous." ${ }^{152}$ This is notably a destructive, negative principle, one that breaks rather than builds up. It further does so by passing judgment on the thing broken, namely, it is something barbarous. No caution is advised, and as such, the principle seems egotistic. This becomes all the more clear when we compare how Evans phrases the same advice (though not his guiding principle): "we should respect grammatical rules that make for clarity, but never be scared to reject rules that seem not to."153 Here, the onus is on the writer to overcome hesitance, fear even, in allowing themselves a lapse of a rule, always accompanied with respect for those rules. This, inter alia, translates into diametrically opposing sentiments on the classic writing guide The Elements of Style by William Strunk and E.B. White; for Favilla, it is her favorite representative of the print world to bash, for Evans it is his gold standard for which to aim.

Meanwhile, the guiding principle of Evans is: "Pity the reader."154 The principle seems mostly to slow authors down and make them think before they write. It is, notably, a top-down statement, one that can easily turn into a paternalistic attitude. The closest equivalent in Favilla's book is when she writes that "it's often crucial to be mindful of respectful and inclusive terminology,"155 which has a more horizontal, peer-to-peer tone to it.

The writing process that those guiding principles encourage is sharply different. Favilla boldly admits that "the relative ephemerality of modern written

\footnotetext{
$150 \quad$ Favilla, p. 16.

151 Evans, pp. 20-21.

$15^{2}$ Favilla, p. 20.

153 Evans, p. 21.

154 Evans, p. 19.

155 Favilla, p. 22.
} 
communication means that there's simply less thought that goes into the words we toss onto a screen." ${ }^{156}$ She celebrates this, saying that "we are no longer slaves [...] in front of a rickety old typewriter."157 Her choice for a typewriter to symbolize anything that would slow us down is interesting, as it is the same symbol that Evans upholds as the ideal writing process. He fondly invokes an image of E.B. White, author of The Elements of Style, writing: "the melodies White made at his typewriter-hesitant bursts of clack-click-ring, with long silences in between and then brooding silences at lunch, worrying about the words he left unfinished."158 Clearly, for Evans, writing should not be ephemeral but an exercise in patience. A typewriter offers patience by making every keystroke a considered decision.

Favilla and Evans consider different aims for writing texts in a digital world. Evans, considering the consequences of a post-truth society, provides a solution typical of print. He argues that "the maelstrom of mendacity makes it all the more imperative that truth be clearly expressed,"159 to which he elsewhere adds that "cyberspace is indulgent, but attention spans are shorter. We appreciate conciseness." 60 Evans, then, aims for short and correct writing, which, indeed, can only be achieved if one meditates on their writing. Favilla, meanwhile, aims for an "acute connection with readers that drives them to engage with and share your content." 161 Truth and brevity can take a backseat because writing "has to scream over the crowd to get the views, the likes, the shares."162 Avoiding untruth only matters for Favilla insofar as it would hurt the trust readers have in you. Even then, it is not about stating something untrue, but it "can lead to a lack of respect for stories you produce in the long run." ${ }^{163}$ Favilla's head is already with the next piece; the engagement you generate now is as an investment to build on and grow in the future.

This, finally, results in two distinctly different envisioned products. Favilla touches on this when she says that "any form of social media allows us to indicate the end of a sentence by pressing 'send.' Unlike analog generations of yore, we often send thoughts piecemeal, rather than as a complete package."164 In the first instance, this statement relates to personal digital communication,

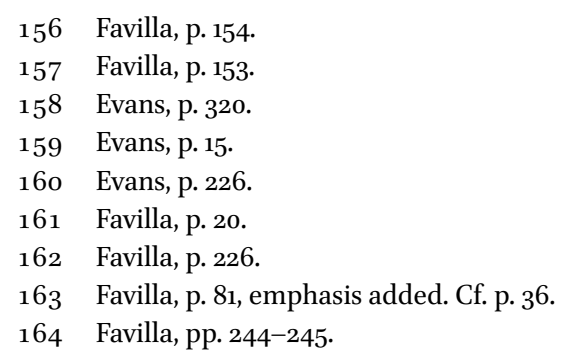


such as text messages. However, I would argue, it also applies to public statements such as tweets, blog posts, and online articles. Favilla is most concerned about the credibility of authors in terms of the likeliness of readers to read the next story, and all that is required right now is an 'acute connection with readers.' Thus, it is more important to get somebody's attention with an unfinished thought as soon as possible than to sit on it and work on refining and completing that thought. There is a similarity here with photography and art. One photograph, we know, does not constitute art, it being merely a mechanical reproduction with little room for artistic intent. But a series of photographs can be art. Similarly, one born-digital text is hardly a finished product, but a series of digital texts can. If you do not get it right the first time or failed to capture an audience, simply say it differently. Text itself is disposable, as the author will continue to convey the message.

The desired product of Evans is neatly captured in a cartoon which he includes in his book. It depicts a casual reader holding a freshly written sheet of paper, standing next to what looks like Shakespeare, who is steaming with anger, a caption reading "Good, but not immortal." 165 Evans included it obviously as an ironic comment, but the irony can only work if we actually believe that writing should strive for immortality. Indeed, Evans speaks of "great writing"166 as our aim and is constantly concerned with bringing down the word count. In short, he is of the school 'say it once, say it well.' Text, thereby, becomes invaluable, carrying the meaning of the author's thoughts independently.

\section{$4 \quad$ Case Study 3: The Written, Printed, and Digital Koran}

Some literature has co-existed with people since time immemorial. The Alexander Romance, for example, or Kalila and Dimna, have been alive for more than two millennia among a great number of cultures and languages. In fact, these stories are very fluid, breaking down in all kinds of versions and subversions, depending on the time, place, language, and undoubtedly other factors. As a consequence, these stories find expression in all the different worlds; manuscript, print, and digital. Other writings need to be retold, too, but they cannot be fluid since they are considered sacred. Examples are the Daoist Tao Te Ching, the Christian New Testament, and the Islamic Koran. Those with knowledge and vested interests in these texts consider themselves as custodians, taking great care in finding the right balance between assuring the

165 Evans, p. 176.

166 Evans, p. 91. 
continued existence of these texts and avoiding aberrations. Observing how such a text moves from one world to another is, therefore, an interesting test case for witnessing the particularities of each world. In this case study, I focus on the Koran, as this holy scripture falls within my field of expertise.

\subsection{From Manuscript to Print}

Even though it is said that Muhammad received revelations orally, they were, from the very beginning, written down and compiled into a book known as the Koran. In fact, the Koran has multiple self-references as a 'book', which makes its identity as a written text all the more easy. One could go even further and argue that the written Koran was what made Islam a civilization of manuscripts more than any other. ${ }^{167}$ The world-making potential of Islam is, I would argue, intimately tied up with the manuscript culture. ${ }^{168}$ It is no wonder, then, that print technology was very slow to be accepted and adopted by Muslims. The first printing of the Koran happened, therefore, not by Muslim hands but Christians in Europe, in Basel and Venice in the 16th century. ${ }^{169}$ Mention is made of an edict (firmān), supposedly issued by Beyazid II in 1485, which would ban any use of the printing press by Muslims. ${ }^{170}$ However, I have been unable to find actual evidence for this order.

The first concerted effort in bringing print into the Islamic world, around 1729, was done by Ibrāhīm Müteferrika, who was of Hungarian-Christian decent but lived most of his life as an Ottoman Muslim. He assured permission from the sultan and the shaykh al-islām, the highest religious authority, together with confirmation of sixteen religious authorities, all active or former judges (sing. $q \bar{a} d \bar{\imath}$ ). Additionally, he wrote an essay entitled Wasīlat al-tibā'a

167 Ahmed, S. What Is Islam? The Importance of Being Islamic. Princeton: Princeton University Press, 2015.

168 Cf. Van Lit, "Commentary and Commentary Tradition."

169 Bobzin, H. "Von Venedig Nach Kairo: Zur Geschichte Arabischer Korandrucke." pp. 151-76 in Sprachen Des Nahen Ostens Und Die Druckrevolution. Eine Interkulturelle Begegnung, edited by G. Roper, D. Glass, and E. Hanebütt-Benz. Westhofen: wva Verlag Skulima, 2002. Arjan van Dijk reconstructs, with some speculation, that the Venice print was meant for export to the Islamic world. After the Ottomans found mistakes in it, it was completely destroyed and the book seller's right hand was chopped off, cf. Dijk, A. van. "Early Printed Qur'ans: The dissemination of the Qur'an in the West." pp. 136-143 in Journal of Qur'anic Studies 7, no. 2 (2005).

170 Larsson, G. Muslims and the New Media: Historical and contemporary debates. Farnham: Ashgate, 2011, p. 33; Oman, G. "Mațba'a", $E I^{2}$, vol. vI, p. 795a; Leemhuis, F. "From palm leaves to the Internet." pp. ${ }^{44-62}$ in The Cambridge Companion to the Qur'ān, edited by J.D. McAuliffe. Cambridge: Cambridge University Press, 2007, p. 152; Abdulrazak, F.A. "The Kingdom of the Book: The History of Printing as an Agency of Change in Morocco between 1865 and 1912." PhD dissertation Boston University, 1990, p. 76. 
about the benefits of printing. We know all of this because Müteferrika inserted these documents at the beginning of the first work he printed. ${ }^{171}$ The firman and the essay have been translated by Christopher Murphy. ${ }^{172}$ The fatwa was translated in English by Skovgaarden-Petersen. ${ }^{173}$ The essay is also available in a modern edition together with a translation and analysis in Persian. ${ }^{174}$ The decree from the sultan, the opinion from the judge, and the essay from the printer all emphasize that what is asked for is the printing of non-religious texts. Clearly, printing a sacred text was seen as a bridge too far.

It will be beneficial to draw from Müteferrika's essay to understand the ramifications of printing the Koran. ${ }^{175} \mathrm{He}$ outlines ten benefits, many of which betray the fundamental differences between the manuscript and print world. Benefit two and three talk about the pristine nature of print. A printed book, according to him, is "stable and enduring," and that if old texts are printed, they are "being restored and invigorated as if they had been recently authored."176 He connects with these thoughts the suggestion that printed books are "safe from mistakes." So, we see that already at this earliest stage of the print world coming about in the Islamic world, print is seen as a pristine end product that definitively replaces moldy manuscripts. ${ }^{177}$ Furthermore, the touchstone of veracity is no longer a long manuscript tradition of many readers selecting the best readings and copying it for future readers, but the publisher. As a fifth benefit, Müteferrika makes mention of page numbers, which he says facilitates immediate and accurate access to a passage, especially when a table of contents and an index is included in the back of the book. Texts until that time generally

171 Jawharī. Tarjama șịhạh al-Jawharī. Translated by Vānqulī, printed by Ibrāhīm Müteferrika. 2 vols., Istanbul: Dār al-țiba'a, 114ıh (1729), pp. i-xvi [pages not numbered]. These texts (except the consent notices of the judges) are in Ottoman Turkish. The relevant pages have been digitized at least twice: Budapest: National Széchényi Library, $\mathrm{H}$ 3252; Qatar: Qatar National Library, PJ6636.T8 J39 1729. The digitized version at McGill does not have these pages and a librarian confirmed that the copy itself does not have them: Montreal: McGill University Library, PJ6620 J382187 1729.

172 Atiyeh, G.N., ed. The Book in the Islamic World: The written word and communication in the Middle East. Albany: suny Press, 1995, pp. 284-285 and pp. 286-292.

173 Skovgaarden-Petersen, J. Defining Islam for the Egyptian State: Muftis and fatwas of the Dar Al-ifta. Leiden: Brill, 1997, p. 73. Also in Larsson, p. 32.

174 Dhawqi, F. "Ibrāhīm Mutafarriqa, Risāle wasīle-ye al-țibā'a wa-tarjama ān.” pp. 234-282 in Payām-i Bihāristān 2, no. 4 (2016).

175 A text closer to the actual printing of the Koran, by Muhammad Haqqi, is mostly a rehash of Müteferrika's arguments, see Abdulrazak, p. 89 .

${ }_{17}$ Much more could be said about the impact of this new perception of texts. For now, let me do with a reference to Robinson, F. "Technology and Religious Change: Islam and the Impact of Print." pp. 229-51 in Modern Asian Studies 27, no. 1 (1993), especially p. 242.

177 Cf. Nichols, "Introduction," p. 3. 
had no page numbering and no index, only a rudimentary table of contents. Müteferrika, then, intuitively understood the immense centrality of the page number for the print world. Thereby, he hints at using a text completely differently from a manuscript to a printed book. Whereas one needs to be introduced to a text in a manuscript gradually and intimately, a printed book can be commanded by a reader much easier. As a seventh benefit, he notes that print publications can "become a foundation for the strength of the empire." In other words, Müteferrika understands how print can centralize power and can forcefully address specific classes of people. He also sees this power cast back onto the ruler - that is to say, that people will actually consent more easily to the government if they display the power of the printing press (benefit eight). He further points out that if the government does not allow Muslims to step into this position of power, others will, as European traders are already knocking at the door wanting to sell print publications (benefit nine). Benefits one, four, six, and ten tie into each other, putting forward the aspect of print that the archive does not attain a status of great power by quality (as manuscripts would, evidenced by the stance of Müteferrika's opponents) or accessibility (as digital documents would, evidenced by altafsir.com's About statement), but by sheer quantity. With this, additionally, Müteferrika emphasizes the educational potential of producing many cheap books.

A century later, in 1833 , at the famous Bulaq Press in Cairo, ${ }^{178}$ it was especially the educational argument that was used to initiate the printing of parts of the Koran. By then, print had proven itself in the Islamic world, or it at least had found a stable place alongside manuscripts. The time was ripe, it seemed, to take the next step and print religious writings. We have a partial record of the back-and-forth between the religious authorities and the printer regarding the project to print excerpts from the Koran. The clergy asked if any parts of the materials used for printing were made of dog skin. ${ }^{179}$ Apparently, it is this materialistic aspect that interested the clergy, being sensitive to the different nature of making the word (and the name) of God come to be by means of a human being writing it by hand and by a machine stamping it. Since apparently no dog skin was involved, the printing went through. The clergy had already been worried about mistakes creeping in, and upon noticing mistakes, they asked for the books to be seized and its sale forbidden. They realized that

${ }_{17}$ Scholars have mentioned earlier prints, including from St. Petersburg, Teheran, Shiraz and Calcutta, but for our case study the Bulaq-episode will suffice. See Bobzin, pp. 166-167; Albin, M.W. “Printing of the Qur'ān.” In Encyclopcedia of the Qur'ān, edited by J.D. McAuliffe, 6 vols., Leiden: Brill, 2004, vol. 4, pp. 264b-276b.

179 Ridwan, A. Ta'rīkh mațba'a bülāq. Cairo: Bulaq, 1953, p. 279 
mistakes in a print publication could have a significant effect on the overall perception of what the text ought to be, as all of a sudden there was not one copy with a mistake in it, but hundreds and, possibly, thousands of copies.

\subsection{From Print to Digital}

It was only in 1924 when a printed edition of the Koran was produced that would make a significant impact. I am talking about the Cairo edition, also known as the King Fu'ād edition, royal ('ämiriyya) edition, or Azhar edition. This printed version of the Koran was eventually accepted by virtually all denominations as a gold standard, from the Wahhabi Saudis to the Twelver Shi'i Iranians. ${ }^{180}$ Most notably, since the eighties, the King Fahd Holy Qurān Printing Complex churned out millions of copies each year of what they call the muṣaf al-Madina, which is equivalent to this Cairo edition. The sheer quantity of this print production has made the medium - the Cairo edition as an abstract idea of a perfect text- the message. One example of this is the extraordinary rise of the Koran's talismanic use. Before, only one or few verses would be engraved, inscribed, or otherwise carried with, but now it is fairly common to see full miniature Korans hanging in cars, on keychains, or printed credit card-size or engraved on a medallion. ${ }^{181}$ The Alifi Qur'ān is another such example, in which the text is typeset to begin every line (on every page) with the letter alif. Only in obscure sub-sub-sects of Islam is manual copying still obligatory. ${ }^{182}$

This one print edition stands in sharp contrast with the seven accepted compilations of the Koran in the manuscript world, which spawned seven additional approved versions, making fourteen readings in total. The variety of these readings is available in print, for sure, ${ }^{183}$ but this seems to be lost on the print mind-set of most people. For, even though the Cairo edition does say at the end that it is only the text according to one reading, that of Hafș, transmitted as by 'Āṣim, it "more or less eclipsed other readings" as Fred Leemhuis

180 Indeed, even the Ibadis from Oman follow the Cairo edition. I make this claim anecdotally and realize a serious grand comparison is long overdue.

181 Cf. Larsson, p. 173; Hirschkind, C. "Media and the Qurān." vol. 3, pp. 341b-349b in Encyclopcedia of the Qur'ān, edited by J.D. McAuliffe, 6 vols., Leiden: Brill, 2004.

182 Akkerman, O. "The Bohra Dark Archive and the Language of Secrecy: A Codicological Ethnography of the Royal 'Alawī Bohra Library in Baroda." PhD dissertation Freie Universität. Berlin, 2015.

183 See Mukhtar Umar, A., and A. Salim Mukarram (eds.). Mújam al-qirā’āt al-qurāniyya. 8 vols. Kuwait: Dhāt al-salāsil, 1988. 
puts it. ${ }^{184}$ So much so that even scholars will refer to it as "the standard text,"185 and some scholars find it problematic that the Koran in the digital world does not fully cohere to it. ${ }^{186}$ Noticeably, websites hosting the Koran rarely mention what reading they use. For example, quran.com relies on the text provided by tanzil.net, which justifies its text by stating: "Tanzil Quran text is carefully derived from Medina Mushaf, which is currently the most authentic copy of the holy Quran (narration of Hafs)." Thus, even though there is a faint notion of the fourteen readings at the very end by referring to Hafs, the main belief propagated is that there is one authentic rendering of the text, the Cairo edition, to the exclusion of the rest. In this, we can see the quintessential spirit of the digital world to have a blinding seduction of usability. As altafsir.com explains its own purpose, it wants to be "instant, safe, user-friendly and easy."

Similarly, whereas in the manuscript world there was a variety of names given to the different chapters (sing. süra), and verse ( $\bar{a} y a)$ numbering was either absent or done in different ways, the Cairo edition solidified both. ${ }^{187}$ The digital world brought this to its logical conclusion, namely, it defines the Koran through numbers. For example, the website quran.com uses a URL structure according to "quran.com $/ \mathrm{x} / \mathrm{Y}$ " with $\mathrm{x}$ as chapter number and $\mathrm{y}$ as verse number.

\subsection{From Digital to Manuscript}

The actual entrance of the Koran into the digital world went by and large unnoticed. Contested issues had already been ironed out with the printing of the Koran and its release on audiovisual media. ${ }^{188}$ Hence, access to the Koran had become thoroughly egalitarian, and its spread over the internet was not seen as a problem. Leemhuis reports a simple metric about the Koran in digital form, by giving the number of hits he got on Google when searching for several spellings of the word Koran. ${ }^{189}$ Below, I contrast his results with mine, showing an explosive fifteen-fold growth.

\footnotetext{
184 Leemhuis, p. $15^{2}$.

185 Puin, G.-R. "Vowel Letters and Ortho-Epic Writing in the Qur'ān." pp. 147-9o in New Perspectives on the Qur'ān: The Qur'ān in Its Historical Context 2, edited by G.S. Reynolds. London: Routledge, 2011.

186 Rippin, A. “The Qur'ān on the Internet: Implications and Future Possibilities." pp. 113-26 in Muslims and the New Information and Communication Technologies, edited by T. Hoffmann and G. Larsson. New York: Springer, 2013.

187 Most notably, Flügel's edition shows differences, cf. Flügel, G. Corani Textus Arabicus. Leipzig: Sumtibus Ernesti Bredtii, 1869.

188 Larsson, p. 184.

189 Leemhuis, p. 158, fn. 13.
} 
TABLE 1.4 Number of hits for keywords concerning the Koran

\begin{tabular}{|c|c|c|}
\hline & 2005 & 2018 \\
\hline Koran & $6,440,000$ & $38,700,000$ \\
\hline Quran & 3,890,000 & $108,000,000$ \\
\hline Qur'an & $1,400,000$ & $39,900,000$ \\
\hline Qurân & 864,000 & 260,000 \\
\hline Bible & 34,800,000 & $485,000,000$ \\
\hline Koran/Bible Ratio & 0.362 & 0.385 \\
\hline
\end{tabular}

It should be noted that this is an overly simple metric, as there might be overlap in hits between "Qur'an" and "Quran," and there are other ways of spelling this word, and most notably we here only compare the English results of the word and not those in Arabic, Persian, Urdu, Turkish, Baha Indonesia, and all the other languages in which one would expect a major online presence of relevant materials for the Koran. Comparing to the Bible on absolute numbers is therefore not relevant, since the number of anglophone people who engage with the Bible is simply larger than those who engage with the Koran. However, we can take the term Bible as a control term. Considering that the ratio stays nearly the same (the Koran slightly winning terrain), it seems this metric does have saying power, and that there is truth in saying that the online presence of the Koran has grown fifteen-fold.

In the previous section, we saw how the digital Koran derives its existence from the printed Koran. However, interestingly enough, among the growth of the digital Koran is a noticeable looping back to its manuscript. The work of Thomas Milo is a prime example in this regard, in particular, two projects of his.

The first one is called Qur'ān Concordance and can be considered as a minimalist digital representation of the Koran. This product stemmed from Milo's observation that anything (even diacritics) beyond the actual lines of the words, the skeleton (rasm) or archigrapheme, was added later. Therefore, he created a digital encoding of just that skeleton, in order to get a more robust representation of what we can know for certain the Koran to have been at its earliest stage. He arrives at this skeleton by taking the Cairo edition and comparing it with the photos of Koran's early fragments. The observable dynamic between the digital and manuscript world is, then, notably different from the 
dynamic between the print and the digital world. Whereas when the print and the digital world meet, they together strive for a singular, unambiguous encoding of the Koran, when manuscript and the digital world meet, they open up the possibility for a multi-interpretable encoding of the Koran that can only reach a human-readable state by computation. Accuracy is a concern for both, but by comparing the encoding to manuscript evidence, accuracy becomes a test for the integrity of manuscripts, not an assumption about the unicity of the text.

Milo's second project is Muṣhaf Musqat, which digitally renders the Koran in a maximally detailed form. ${ }^{190}$ This project relies on the 'Advanced Composition Engine' (ACE) developed by his company DecoType, which can typeset a script in a more flexible way than conventional font technology. An example of the advantage of Mușhaf Musqat over the typesetting of the Cairo edition can be seen by considering the snippet of text "shurakāa khalaqū ka-khalqihi" from Sura $a l-R a^{c} d(13)$, verse 16 , as given in the illustrations below:

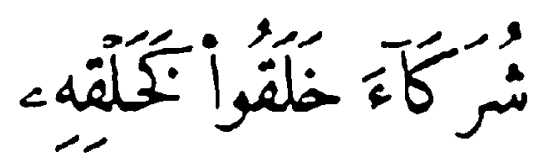

FIGURE 1.1A Example from Cairo edition

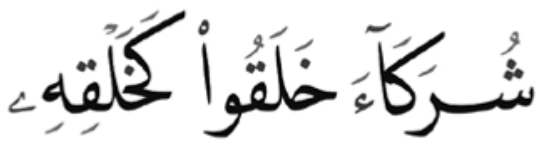

FIGURE 1.1B Example from Muscat edition

We only need to consider the last word group, ka-khalqihi, "like His creation." Notice how the angle of the first letter, the $k \bar{a} f$, is significantly blunter than the $k \bar{a} f$ in the first word, in the Cairo edition. This is, it seems, only so that the $k \bar{a} f$ remains within the 'rails' of the typesetting. We also see that the dot of the second letter, the $k h a^{\prime}$, is placed to the right of the $k \bar{a} f$, apparently for no other reason than that it was easier to typeset it that way. In Milo's version, the two $k \bar{a} f \mathrm{~s}$ have an identical angle and the dot is restored to its place to the left of the $k \bar{a} f$, above the $k h a^{\prime}$. In other words, this digital rendering restores the correct

190 For a history and evaluation of DecoType's work, see Nemeth, T. Arabic Type-Making in the Machine Age: The Influence of Technology on the Form of Arabic Type, 1908-1993. Leiden: Brill, 2017, pp. 410-434. Nemeth concludes that "the contribution of DecoType to Arabic type-making has been remarkable and its influence is here to stay." 
way of writing Arabic, as attested in manuscripts, against the printed edition which saw itself limited by its own technology.

Beyond these improvements, Milo's software gives users the control to change the appearance of the text as far as the script allows. In this case, the space between the last two letters, the $q \bar{a} f$, and the $h a^{2}$, can be elongated, the shape of the $k \bar{a} f$ can be changed, the two dots above the $q \bar{a} f$ can be arranged

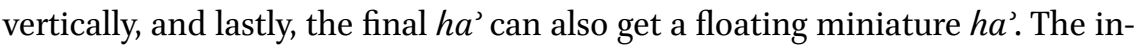
teractivity of the digital world is, thereby, optimally used, exactly to give back some of the fluidity and variety of the manuscript world. We see, then, an interesting reach from the digital world towards the manuscript world, one that can subvert the hegemony of the print world.

Consequences for Digitized Manuscripts

We have seen how the manuscript, print, and digital world can, at times, fold into each other and at times, go different ways. Their world views, their epistemes, are different. What happens when manuscripts and digital documents are meshed together? This could, of course, go in two different manners. One is that the contents of the manuscript are converted to digital format; the other is that the appearance of the manuscript is converted to digital format. The first option can be fairly well analyzed with the case studies just discussed, and we will look further into it in Chapter Five. In Chapter Two, we will consider the second option, which is the more pertinent one: when people speak of digitizing manuscripts, they mean taking digital photos of it. These photos could be of a full folio or part of it; they could be one or many, and they can be stored as they are or within a software environment that dictates the way we access them. The photos themselves can vary in quality, depending on the camera and the studio conditions, and also the post-processing. Lastly, using digital photos of manuscripts means we are operating in multiple worlds at once. Through the digital world, we engage with objects of the manuscript world. Moreover, this takes place in a time when the print world still looms large; for example, we often work towards creating a print publication. Given the vastly different world views these different worlds entail, working with manuscripts on a computer towards a print publication is a process in which we can make many false assumptions or fail to realize new opportunities. It is, then, time to seriously consider what it means to work with a digitized manuscript, in the next chapter. 